\title{
Trafikdryckenskap \\ som social och socialmedicinsk problem
}

\author{
Av prof. SVEN ERKKILÄ, Åbo.
}

\section{Inledning}

Brottsligheten har hos oss i Finland under den gångna decenniet fortfarande tilltagit i synnerhet i städer och övriga bosättningscentra. Varav härflyter brottsligheten och enkannerligen den kraftiga stegringen $\mathrm{i}$ av ungdom begångna brott, då den ekonomiska utvecklingen förbättrats och den omedelbara bristen bemästrats och enär i samtliga branscher betydande förbättringar ägt rum? Fenomenet är på sätt och vis allmänvärldsligt. Just i välfärdsländerna som t. ex. Förenta Staterna, England och Sverige utgör brottsligheten en ännu större svårighet än hos oss. Välståndet förefaller inte att medföra uteslutande tillfredsställelse, utan även missnöje, som i synnerhet hos ungdommen lätt leder till brottsliga handlingar.

Som en särskilt betecknande orsak till brottens tillväxt bör anses den omständigheten, att urvalet av tillfällen och lockelser är betydligt rikligare än tillförne. Ju rikligare tillfällen till brott förekommer, desto mer begås de även. Den enorma tekniska och industriella expansionen har utvecklats därhän, att människorna har nu för tiden allt större materiella resurser. Den kraftiga stegringen av bilstölderna t. ex. under senaste decennium kan till stor del tillskrivas bilparkens mångfaldiga ökning. Att lämna bilarna olåsta på gatan och för övrigt vårdslösa service skapar stegrade frestelser till „,billån“ och bilstölder. Enär dessutom åtkomsten av vissa alkoholhaltiga drycker och övriga berusninigsmedel blivit allt lättare, har följden härav blivit, att bl. a. fylleriförseelserna $\mathrm{i}$ trafiken hos oss under senare år ansenligt stigit. Sagda förseelserubrik har även numera blivit ett allt större problem förutom från kriminologisk även från social och socialmedicinsk ståndpunkt. Användandet av alkohol och övrige berusningsmedel i samband med trafiken har sedan länge konstaterats särdeles farligt. Detta berör inte enbart ordinära fyllerifall, utan redan en ringa kvantite inmundigad alkohol inverkar på trafiksäkerheten. Till och med ringa kvantiteter alkohol förslappar uppmärksamheten, nedsätter självkritiken, omdömes- och iakttagelseförmågan, synens skärpa, observationen och reaktionssnabbheten.

Vår vägtrafikanlag, som är en av de rigorösaste i Europa, förutsätter absolut nykterhet vid framförande av motorfordon. Sagda lag förordnar följande: Den som framför på väg eller offentligt ställe motorfordon under inverkan av alkohol eller annat be-

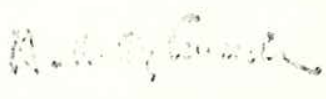


rusningsmedel, må dömas till fängelse eller tukthus under högst tre år, eller såframt förseelsen inte föranlett fara för den allmänna säkerheten eller förmildrande omständigheter annars föreligger, till bötesstraff.

Trafikfylleri, vars samhälleliga betydelse är särskilt stor, utgör ett svårt och komplicerat problem, vars lyckliga lösning förutser förutom kriminologisk, bl. a. rättskemisk, social och socialmedicinsk forskning. Man borde bl. a. följa med utvecklingskurvan för trafikfylleriförseelserna och däri medverkande faktorer, utforska de förseelseskyldigas fördelning med hänsyn till ålder och socialt status, klarlägga fyllerigraden under körningen, vilka slags alkoholhaltiga drycker och övriga berusningsmedel använts och i vilka mängder jämte storleken av de åsamkade skadorna och sträva efter att få till stånd för våra förhållanden lämpliga preventiva åtgärder för förseelsernas nedkämpande.

\section{Källuppgifter}

Min forskning omfattar de i Helsingfors / invånarantal ca. 450.000 / åren 1958-1961 och de i Åbo / invånarantal ca. 105.000 / åren 1960-1963 uppdagade rattfylleriförseelserna, i vilka fall fylleriet har varit till den grad uppenbart, att kriminalpolisen anmält förseelserna till domstol. Under sagda tider har antalet för rattfylleri anklagade i Helsingfors varit 1.679 och i Åbo 528 .

Forskningsmaterialet har införskaffats från Helsingfors och Åbo polisinrättningars polisrannsakningsprotokoll och anmälningar om brott. De rannsakade personerna var av manligt kön med undantag av 2; på grund av fåtalet kvinnor lämnades de ur räkningan.

\section{Åldersgrupper}

Tabell 1. Fördelning av trafikfyllerister i Helsingfors på olika åldersgrupper åren $1958-61$.

\begin{tabular}{lrrrrrrrrr}
\hline Ålder & \multicolumn{1}{c}{ Absol.antalet trafikfyllerister och i $\%$} & \multicolumn{3}{c}{$\begin{array}{c}\text { Medeltal } \\
\text { i \% }\end{array}$} \\
\hline Under 20 år & 21 & 5,7 & 11 & 3,0 & 15 & 3,6 & 35 & 6,5 & 4,7 \\
$20-29$ år & 160 & 43,7 & 120 & 32,5 & 113 & 27,7 & 153 & 28,5 & 33,1 \\
30 -39 år & 106 & 28,9 & 144 & 39,0 & 148 & 36,2 & 189 & 35,4 & 34,8 \\
$40-49$ år & 69 & 18,9 & 57 & 15,4 & 90 & 22,0 & 114 & 21,2 & 19,4 \\
över 50 år & 10 & 2,8 & 37 & 10,1 & 43 & 10,5 & 45 & 8,4 & 8,0 \\
Året för & & & & & & & & & \\
händelser & 1958 & 1959 & 1960 & 1961 & \\
Atalade & 366 & 369 & 409 & 535 & \\
\hline
\end{tabular}


Under åren 1958 - 1960 var den yngsta trafikfylleristens ålder 16 år, men 1961 endast 12 år. Den kriminalrättsliga ansvarigheten börjar hos oss icke förrän individen fyllt 15 år, varför i detta fall saken behandlats av barnskyddsmyndigheterna. Den äldsta var 195879 år, 195974 år, 196066 år och 196159 år. Orsaken till det anmärkningsvärt låga antalet individer under 20 år bör otvivelaktigt tillskrivas den omständigheten, att i Finland får endast 18 år fyllda individer bilkörkort. En del av dem till denn yngre åldersklassen hörande utgörs av mopedister eller motorcykel-körande personer. Motorcykel, vars egen vikt inteöverstiger 50 kilo och med bränslemotorvolym inte över $50 \mathrm{~cm}^{3}$, får köras endast av individ som fyllt 15 år utan att inneha körkort, likmätigt förordningen om motorfordon. Av dem, som gjort sig skyldiga till trafikfylleri, utgör mopedisternas antal ungefär en femtedel per år. Åldersgruppen 30-39 år / 34.9 \% / representerade lejonparten i trafikfylleristatistiken. På andra plats kom åldersgruppen 20 -29 år / 33.1 \% /, varför de 20-39 årigas andel utgjorde $68 \%$ av fallen.

I Åbo har trafikfyllerister anhållits år 1960 105, 1961 123, 1962 140, och 1963 160. Antalet förseelser ger vid handen en stadigt stigande tendens. En sådan extremt häftig stegring som i Helsingfors ägde rum år 1961 har man icke kunnat anteckna i Åbo.

Trafikfylleriförseelsernas fördelning i olika åldersgrupper har i Åbo ägt rum på ett likartat sätt som i Helsingfors. I materialet är medelåldern 35 år eller så gott som enahanda med Helsingfors trafikfyllerister. Medelåldern för bilfyllerister i Åbo var under åren 1960-1961 31 år, då däremot mopedfylleristernas medelålder under samma år var 39 år.

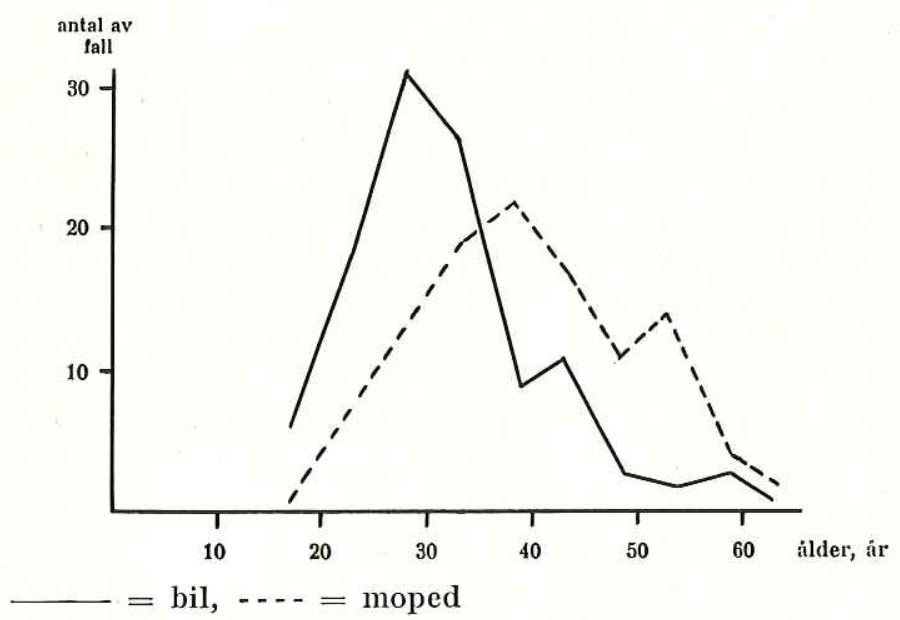

Bild 1. Trafikfylleristernas fördelning enligt ålder i Åbo åren 1960—61. 
I Åbo är alltså bilfylleristerna yngre personer än de trafikfyllerister som begagnar sig av moped.

I trafikfylleriförseelsernas fördelning på de olika månaderna såväl i Helsingfors som i Åbo framgår tydligt klimatets inverkan, ty under de kalla vintermånaderna minskas motorfordonnens användning, enkannerligen mopedernas, och tilltar igen vid det milda klimatets inbrott. I enlighet med mitt material är de lugnaste månaderna februari och januari. Enligt hela landet omfattande forskningsresultat av A. Alha var januari den stillsammaste månaden under åren $1960-64$. I enlighet med mitt material har jämförelsevis det största antalet både bil- och mopedfyllerifall inträffat i juli, vid vilken tid motorfordonstrafiken är som livligast. På andra plats har mestadels kommit september och oktober, vilket torde kunna tillskrivas inverkan av belysningsförhållandenas försämring. Den i bild 2 i november från biltrafikfyllerifallen härrörande höjdpunkten har kunnat föranledas av t. ex. dåligt väglag.

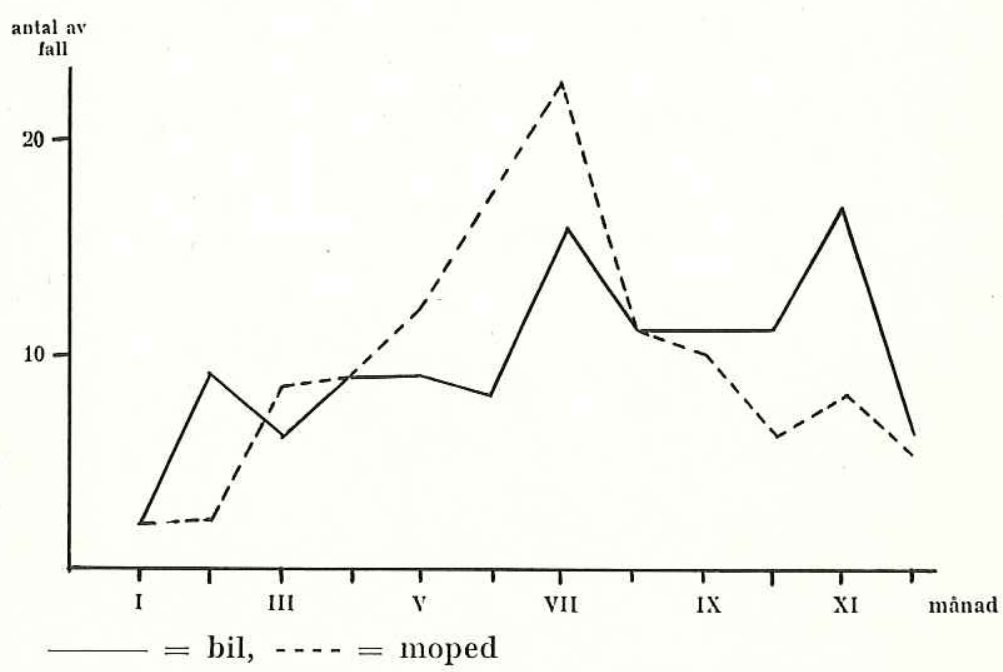

Bild 2. Trafikfylleriförseelsernas fördelning på de olika månaderna Åbo åren $1960-61$.

Det är klart, att trafikfyllerifallen fördelas någorlunda regelbundet på de skilda veckodagarna. Weckendens livliga trafik och stegrade alkoholkonsumtion framträder klart i bild 3, som presenterar trafikfyllerifallens i Åbo fördelning på skilda veckodagar under åren 1960-1961. 


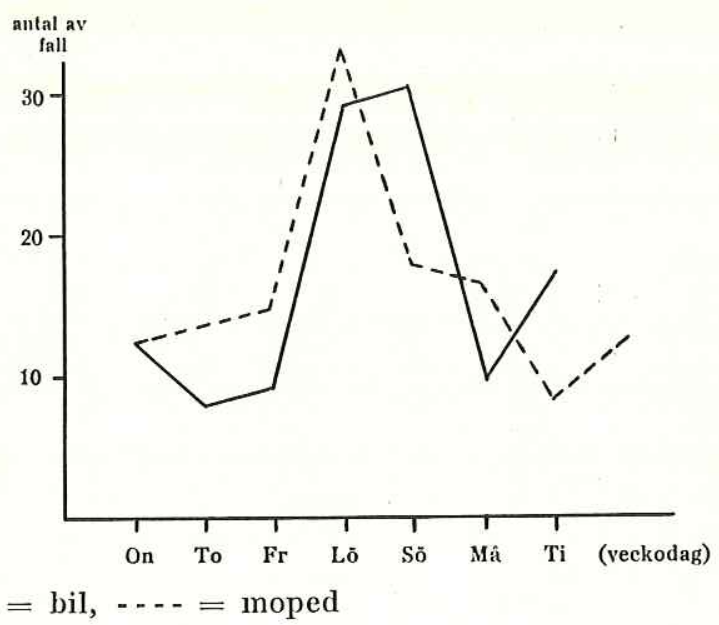

Bild 3. Trafikfylliförseelsernas fördelning på olika veckodagar i Åbo $1960-61$.

Under rannsakningsskedet har i Helsingfors så gott som hälften av fallen kommit till polisens kännedom under dygnets sista kvart. Ett jämförelsevis stort antal / ca 30 \% / har även uppdagats under dygnets första kvart. Den andra kvarten har däremot karakteriserats som en stiltjeperiod i högsta grad.

\section{Fördelning av motorfordon enligt trafikfylleristernas ålder}

Av de motorfordon, som trafikfylleristerna i Helsingfors använder, utgör personbilen den vanligaste; över $50 \%$ faller på personbilars del. För individer, som fyllt 50 år, är bilen i dominerande grad det mest använda motorfordonet. På andra plats bland använda fordon kommer moped / ca. $20 \%$ / som blivit vida utbredd på kort tid, och på tredje plats kommer vanligast, på grund av arbete och yrke, lastbilen och paket- eller farmarbilen $/ 9.0 \% /$. Det allmännaste fordonet för individer under 20 år är motorcykeln. 20-29-åringar kör mest med personbilar; detsamma gör även individer äldre än dessa. Efter 30-årsåldern blir motorcyklarnas andel obetydlig. Trenne linjebilar väcker även uppmärksamhet. Visserligen gjorde de inte turer för allmänheten, utan montörerna provkörde dem för att konstatera deras skick efter reparationen. Man bör lägga märke till att traktorernas andel under år 1961 betydligt stigit och anslutit sig till sådana åldersgrupper däri de åtminstone under de föregående tvenne åren icke figurerat. 
Tabell 2. Fördelning av motorfordon på trafikfyllerister i Helsingfors enligt ålder i \% åren 1959-61.

\begin{tabular}{|c|c|c|c|c|c|c|c|}
\hline Motorfordon & år & $\begin{array}{c}\text { under } \\
20 \text { år }\end{array}$ & $20-29$ & $30-39$ & $40-49$ & $\begin{array}{c}\text { över } \\
50 \text { år }\end{array}$ & $\begin{array}{c}\text { I } \% \text { av } \\
\text { hela antalet }\end{array}$ \\
\hline Moped & $\begin{array}{r}1959 \\
-60 \\
-61\end{array}$ & $\begin{array}{r}27,3 \\
6,7 \\
22,9\end{array}$ & $\begin{array}{r}6,7 \\
16,8 \\
17,6\end{array}$ & $\begin{array}{l}24,3 \\
25,7 \\
22,7\end{array}$ & $\begin{array}{l}24,6 \\
26,6 \\
15,8\end{array}$ & $\begin{array}{l}21,6 \\
11,6 \\
24,4\end{array}$ & $\begin{array}{l}18,4 \\
21,3 \\
20,0\end{array}$ \\
\hline Motorcykeln & $\begin{array}{r}1959 \\
-60 \\
-61\end{array}$ & $\begin{array}{l}45,4 \\
46,6 \\
25,7\end{array}$ & $\begin{array}{r}10,0 \\
8,0 \\
9,2\end{array}$ & $\begin{array}{l}4,2 \\
4,8 \\
3,7\end{array}$ & $\begin{array}{l}5,2 \\
5,6 \\
2,6\end{array}$ & $\begin{array}{l}2,7 \\
9,3 \\
2,2\end{array}$ & $\begin{array}{l}7,3 \\
7,8 \\
6,4\end{array}$ \\
\hline Personbil & $\begin{array}{r}1959 \\
-60 \\
-61\end{array}$ & $\begin{array}{l}18,1 \\
40,0 \\
40,0\end{array}$ & $\begin{array}{l}55,8 \\
51,3 \\
48,3\end{array}$ & $\begin{array}{l}51,4 \\
49,3 \\
49,0\end{array}$ & $\begin{array}{l}43,9 \\
53,3 \\
61,4\end{array}$ & $\begin{array}{l}70,3 \\
65,1 \\
48,9\end{array}$ & $\begin{array}{l}52,6 \\
52,1 \\
51,9\end{array}$ \\
\hline $\begin{array}{l}\text { Paket- eller } \\
\text { farmarbil }\end{array}$ & $\begin{array}{r}1959 \\
-60 \\
-61\end{array}$ & $\begin{array}{l}-\overline{6,7} \\
2,9\end{array}$ & $\begin{array}{r}11,0 \\
9,7 \\
13,7\end{array}$ & $\begin{array}{r}6,9 \\
6,1 \\
11,1\end{array}$ & $\begin{array}{r}12,3 \\
5,6 \\
11,4\end{array}$ & $\begin{array}{r}5,4 \\
7,0 \\
11,1\end{array}$ & $\begin{array}{r}8,7 \\
7,1 \\
11,4\end{array}$ \\
\hline Lastbil & $\begin{array}{r}1959 \\
-60 \\
-61\end{array}$ & $\frac{9,2}{5,6}$ & $\begin{array}{r}13,3 \\
14,2 \\
8,5\end{array}$ & $\begin{array}{r}11,8 \\
9,4 \\
10,1\end{array}$ & $\begin{array}{r}14,0 \\
8,9 \\
5,2\end{array}$ & $\begin{array}{l}-\overline{7,0} \\
8,8\end{array}$ & $\begin{array}{r}11,4 \\
10,0 \\
6,3\end{array}$ \\
\hline Linjebil & $\begin{array}{r}1959 \\
-60 \\
-61\end{array}$ & - & $\frac{1,6}{1,9}$ & $\begin{array}{l}0,7 \\
2,0 \\
1,0\end{array}$ & $\overline{-}$ & - & $\begin{array}{l}0,8 \\
0,7 \\
1,3\end{array}$ \\
\hline Traktor & $\begin{array}{r}1959 \\
-60 \\
-61\end{array}$ & $\overline{-}$ & $\frac{1,6}{0,7}$ & $\begin{array}{l}0,7 \\
2,7 \\
1,5\end{array}$ & $\frac{\bar{Z}}{1,7}$ & $\frac{\overline{-}}{4,4}$ & $\begin{array}{l}0,8 \\
1,0 \\
1,6\end{array}$ \\
\hline
\end{tabular}

Fördelning av trafikfyllerister på olika socialgrupper

Individens sociala status är ofta en betydelsefull faktor till hans attityd gentemot bruket av alkohol. Har detta även något sammanhang med rattfylleri?

Vid klassificering av individen på basis av hans ordinarie verksamhet finns det många olika möjligheter att välja på. Som språngbräde kan man ta olika yrkesgrupper, lönebelopp, skolutbildning etc. I denna forskning tillämpas en socialgruppering, grundande sig på den samhälleliga värdesättning som olika fack åtnjuter.

Vid klassificeringen av trafikfyllerister tillämpades följande gruppering:

I. Absolverat akademisk slutexamen och i ledande ställning.

II. Självständiga yrkesidkare, affärsmän, „högre“ icke akademiska tjänstemän. 
III. Yrkesarbetare, „lägre“ tjänstemän.

IV. Studerande och skolelever.

V. Icke yrkesfärdiga arbetare och icke verksamma i yrke.

Tabell 3. Fördelning av till trafikfylleri i Helsingfors skyldiga på olika socialgrupper åren 1958-61.

\begin{tabular}{lrrrrrrrrr}
\hline $\begin{array}{l}\text { Social- } \\
\text { grupper }\end{array}$ & \multicolumn{1}{c}{ Absol.antalet skyldiga och i $\%$} & \multicolumn{3}{c}{$\begin{array}{c}\text { Medeltal } \\
\text { i \% }\end{array}$} \\
\hline I & 45 & 12,3 & 15 & 4,1 & 13 & 3,1 & 10 & 1,9 & 5,4 \\
II & 89 & 24,3 & 53 & 14,4 & 70 & 17,1 & 70 & 13,1 & 17,2 \\
III & 161 & 44,0 & 226 & 61,2 & 227 & 55,5 & 316 & 59,1 & 54,9 \\
IV & 2 & 0,5 & 8 & 2,2 & 16 & 4,0 & 11 & 2,1 & 2,2 \\
V & 69 & 18,8 & 67 & 18,1 & 83 & 20,3 & 128 & 23,8 & 20,3 \\
Året för & & & & & & & & & \\
händelsen & 1958 & 1959 & 1960 & 1961 & \\
Skyldiga & 366 & 369 & 409 & 535 & \\
\hline
\end{tabular}

Över hälften av fallen hör till den tredje socialgruppen, där yrkesarbetarena utgör det dominerande inslaget. Av dessa är igen bilisterna och bilmontörerna särdeles rikligt representerade i täten. Den III gruppens storlek känns naturlig då man tar i beaktande, att denna grupp även i städernas normala population är hög och att denna grupp är till största delen sammansatt av yrkesarbetare, vars inkomstnivå är känd att vara tillräckligt hög för anskaffande av motorfordon, men vars ansvarighetskänsla och samhällsmoral är kanhända ännu outvecklade. Sålunda tror många bilmontörer, som är bättre än andra hemmastadda i motorfordonens konstruktion, att de även under alkoholens inflytande känner sitt fordon väl och är i stånd till att köra det.

Även gruppen omfattande icke yrkeskunniga och i yrke icke verksamma individer är rätt stor $/ 20.3 \% /$. På grund av förvärvsmöjligheternas förbättring och levnadsstandardens stegring synes även denna socialgrupp ha råd till att hålla sig med motorfordon.

Självständiga yrkesidkare, affärsmän och „högre“ icke akademiska tjänstemän förekommer jämförelsevis rikligt i materialet / $17.2 \%$ /. En anmärkningsvärd del av dessa är affärsmän, olika representanter, som i samband med förhandlingar, förevisningar och affärer förtär alkoholhaltiga drycker.

Deras antal som hör till den första socialgruppen är överraskande lågt / $5.4 \%$ /. Även individerna i den IV socialgruppen, studerande och skolelever är få till antalet $\mathrm{i}$ jämförelse med deras relativa mängd i Helsingfors. Till den sistnämnda gruppens för- 
fogande har givetvis stått det minsta antalet bilar på grund av elkonomiska orsaker.

Vi kan konstatera, att i de socialgrupper, där de sociala förhållandena varit klenast, har trafikfylleriet predominerat.

\section{Fordon i olika socialgrupper}

Tabell 4. Fordon i olika socialgrupper i Helsingfors material i \% åren åren $1959-61$.

\begin{tabular}{|c|c|c|c|c|c|c|c|}
\hline Motorfordon & År & I & II & III & IV & V & $\begin{array}{c}\text { I } \% \text { av hela } \\
\text { antalet }\end{array}$ \\
\hline Moped & $\begin{array}{r}1959 \\
-60 \\
-61\end{array}$ & $\begin{array}{l}- \\
-\end{array}$ & $\begin{array}{l}5,7 \\
2,9 \\
7,1\end{array}$ & $\begin{array}{l}16,8 \\
23,7 \\
17,1\end{array}$ & $\begin{array}{l}- \\
6,2 \\
-\end{array}$ & $\begin{array}{l}44,3 \\
44,6 \\
40,6\end{array}$ & $\begin{array}{l}18,4 \\
23,3 \\
20,4\end{array}$ \\
\hline Motorcykeln & $\begin{array}{r}1959 \\
-60 \\
-61\end{array}$ & $\begin{array}{l}- \\
-\end{array}$ & $\overline{-}$ & $\begin{array}{l}7,5 \\
5,7 \\
3,5\end{array}$ & $\begin{array}{l}25,0 \\
25,0 \\
36,3\end{array}$ & $\begin{array}{r}13,1 \\
8,5 \\
12,5\end{array}$ & $\begin{array}{l}7,3 \\
5,8 \\
6,0\end{array}$ \\
\hline Personbil & $\begin{array}{r}1959 \\
-60 \\
-61\end{array}$ & $\begin{array}{r}100,0 \\
92,3 \\
100,0\end{array}$ & $\begin{array}{l}84,9 \\
82,8 \\
64,2\end{array}$ & $\begin{array}{l}46,9 \\
46,8 \\
53,8\end{array}$ & $\begin{array}{l}75,0 \\
43,8 \\
54,5\end{array}$ & $\begin{array}{l}26,2 \\
34,9 \\
31,3\end{array}$ & $\begin{array}{l}52,6 \\
52,0 \\
50,4\end{array}$ \\
\hline $\begin{array}{l}\text { Paket- eller } \\
\text { farmarbil }\end{array}$ & $\begin{array}{r}1959 \\
-60 \\
-61\end{array}$ & $\overline{7,7}$ & $\begin{array}{r}7,5 \\
5,7 \\
21,4\end{array}$ & $\begin{array}{r}11,0 \\
8,4 \\
11,1\end{array}$ & $\begin{array}{r}- \\
12,5 \\
9,2\end{array}$ & $\begin{array}{l}4,9 \\
3,6 \\
6,5\end{array}$ & $\begin{array}{r}8,7 \\
7,0 \\
11,2\end{array}$ \\
\hline Lastbil & $\begin{array}{r}1959 \\
-60 \\
-61\end{array}$ & $\frac{-}{-}$ & $\begin{array}{l}1,9 \\
8,6 \\
5,9\end{array}$ & $\begin{array}{r}15,5 \\
12,8 \\
9,8\end{array}$ & $\underline{12,5}$ & $\begin{array}{l}9,9 \\
6,0 \\
7,8\end{array}$ & $\begin{array}{r}11,4 \\
10,3 \\
8,4\end{array}$ \\
\hline Linjebil & $\begin{array}{r}1959 \\
-60 \\
-61\end{array}$ & - & - & $\begin{array}{l}1,3 \\
1,3 \\
2,2\end{array}$ & - & - & $\begin{array}{l}0,8 \\
0,7 \\
1,3\end{array}$ \\
\hline Traktor & $\begin{array}{r}1959 \\
-60 \\
-61\end{array}$ & E & - & $\begin{array}{l}1,0 \\
1,3 \\
2,5\end{array}$ & - & $\begin{array}{l}1,6 \\
1,2 \\
1,3\end{array}$ & $\begin{array}{l}0,8 \\
0,9 \\
2,3\end{array}$ \\
\hline
\end{tabular}

I den första socialgruppen, för dem som absolverat akademisk slutexamen, representerar fordonet även deras levnadsstandard. De till denna grupp hörande rattfylleristerna äger personbil så gott som 100-procentigt. En likartad tendens fortsätter även i den II socialgruppen. Ca 77 \% utgörs av personbilar. Som utkomstkälla är lastbilarnas andel naturligtvis ansenlig i tredje gruppen. Det oaktat intar personbilarna även i denna socialgrupp första plats. Av representanter använda paket- och farmarbilar bör man 
även lägga märke till. Antalet billigare fordon stiger när levnadsnivån faller. Detta framgår tydligt för mopedernas vidkommande i den V gruppen, där de mest förekommer.

\section{Rusets variationer under bilfärden $i$ olika åldersgrupper}

Ruset konstateras förmedels fastställande av alkoholhalten i blodet och klinisk undersökning. Vanligen differentierar man i ruset trenne olika faser, vars fastställande baseras på alkoholförtäringens initial- och slutperioder. Rusets uppkomstfas framträder då alkoholförtäringen har avslutats ej över två timmar innan den kliniska undersökningen. Rusets korta nedgångsfas förutsätter, att sedan alkoholförtäringens avslutande från två till fem timmar förflutit. Rusets långa nedgångsfas kommer i fråga i sådana fall, där över fem timmar förflutit sedan alkoholförtäringen.

När vi undersöker rusets faser under färden hos de åtalade i olika åldersgrupper grunder sig uppgifterna på av de åtalade om sig själva lämnade upplysningar rörande den förtärda alkoholmängden och sorten ävensom tidpunkten för förtäringen. Av välförstådda skäl håller de lämnade upplysningarna inte streck i alla avseenden. Det torde observeras, att på ovannämnda basis fastställt rus avser fas eller slag, då däremot av läkare fastställt rus vid skedet för undersökningen anger dess „,styrka“. I läkareutlåtandet anges vanligen inte rusets faser då promillemängderna alkohol i det undersökta blodet var till den grad höga eller ruset var så uppenbart, att ett fixerande av rusets faser inte befunnits nödigt. Dessa fall är i följande tabell, belysande i Helsingfors år 1959 förekommande berusningsfaser, rubricerade som „,inga faser“. De, som vägrat blodprov, är även upptagna i denna tabell ävensom de, om vilka läkarutlåtande inte finns; angivelserna är även medtagna. I Finland blev tagandet av blodprov obligatoriskt inte förrän den 1 augusti 1959.

Tabell 5. Fyllerifasen i olika åldersgrupper i Helsingfors material i \% år 1959.

\begin{tabular}{|c|c|c|c|c|c|c|}
\hline Ålder & $\begin{array}{l}\text { under } \\
20 \text { år }\end{array}$ & $20-29$ & $30-39$ & $40-49$ & $\begin{array}{l}\text { över } \\
50 \text { år }\end{array}$ & $\begin{array}{l}\text { I \% av hela } \\
\text { antalet }\end{array}$ \\
\hline Inga faser & 9,4 & 46,7 & 52,8 & 54,4 & 43,2 & 48,8 \\
\hline Stigande fylla & 36,3 & 21,6 & 20,1 & 26,3 & 37,9 & 23,8 \\
\hline Kort sjuknande fylla & 18,1 & 4,2 & 4,9 & 1,8 & 2,7 & 4,3 \\
\hline Sjuknande fylla & 18,1 & 10,0 & 5,5 & 3,5 & 2,7 & 6,8 \\
\hline Lång sjuknande fylla & $a-$ & 5,0 & 2,1 & - & 5,4 & 3,0 \\
\hline Vägrat blodprov & - & 6,7 & 8,3 & 5,2 & 2,7 & 6,5 \\
\hline $\begin{array}{l}\text { Inga läkarintyg } \\
\text { och angivelser }\end{array}$ & 18,1 & 5,8 & 6,3 & 8,8 & 5,4 & 6,8 \\
\hline
\end{tabular}


Individer under 20 år har i de flesta fall kört i ett tillstånd av rusets stigande $/ 36.3 \% /$, d. v. s. omedelbart efter förtäring av alkohol. Kanhända har de inte varit tillräckligt kritiska mot sig själva eller förlitat sig på god tur då de omedelbart efter förtäring av alkohol farit ut och åka. Bland 20-29åringar har så gott som hälften utgjort uppenbara berusningsfall / 46.1\% /. I ett tillstånd av rusets stigande har bland dessa antecknats $21.6 \%$. Antalet individer $\mathrm{i}$ ett tillstånd av rusets nedgång har varit rätt obetydligt alldeles som bland äldre åldersgrupper. Antalet blodprovsvägrare är $6.7 \%$. Den övervägande delen av detta procenttal gäller 30-39åringar / $8.3 \%$ /. Denna åldersgrupp uppvisar säkra fyllerifall över hälften / $52.8 \%$ /. I ett tillstånd av stigande fylla har i denna grupp kört bilar $20.1 \%$. Hos 40 - 49åringarna tangerar ,,inga faser"-fallen klimax / $54.4 \%$ /. Likaledes har antalet individer med stigande fylla tilltagit / $26.3 \% /$, i hvilket sammanhang den största mängden faller på individer över 50 år / $37.9 \% /$.

När vi studerar samtliga fall i ovanstående tabell framgår det att säkra fyllerifall utgör ungefär hälften och stigande fyllerifall omkring en fjärdedel. I de olika faser av tillnyktring har det i stora drag funnits lika mycket / $3-7 \% /$.

Vid gruppering av ovannämnda material för år 1960 från åldersposition i sociala grupper, uppkommer i fyllerifasernas fördelning inga nämnvärda förändringar. „Inga faser"-fall förekommer oftast i den första socialgruppen / $53.3 \%$ /. I övriga socialgrupper utgör de säkra fallen ungefär hälften. Individer med stigande fylla intar i varje socialgrupp andra plats. I stora drag är deras antal en fjärdedel. Individer i olika stadier av tillnyktring är till antalet nästan lika många / 4-6\% / i varje socialgrupp. Blodprovsvägrare förekommer rikligast i andra socialgruppen / $15.1 \% /$.

I detta sammanhang torde det inte vara skäl att närmare ingå på frågan om alkoholhalten i trafikfylleristernas blod under åkningen, ty frågan är närmast av rättsmedicinsk natur och biträdande professorn Antti Alha har på ett förtjänstfullt sätt klargjort denna sak hos oss i sina många forskningar. Jag kan endast konstatera, att $\mathrm{i}$ vår lag finns inte omnämnt alkoholens promillehalt $i$ blodet, enligt vilken bilchaufför kan anhållas som varande under alkoholens inverkan. Denna omständighet innebär otvivelaktigt en fördel för lagen, ty på grund av alkoholens individuella inverkan, är det omöjligt att fullt allmängiltigt bestämma, vilken inverkan varje alkoholmängd och -sort i allmänhet har. Utöver den individuella känsligheten är alkoholreaktionen beroende förutom av den förtärda mängden och kvaliteten även av snabbheten och användningsformen. Även vanan att handskas med alkohol påverkar den av känslighet fixerade ,retningströskeln“. Det har konstaterats, att personer i intellektuellt arbete förefaller 
i allmänhet vara $i$ stånd till att bibehålla jämvikten i sitt uppförande under alkoholets inverkan bättre än kroppsarbetare. Widmarks system tillämpas hos oss för att konstatera alkoholhalten i blodet och undersökningarna äger rum i rättskemiska avdelningen av rättsmedicinska anstalten vid Helsingfors Universitet, förman prof. Unto Uotila, som direktör bitr. prof. Antti Alha.

\section{Den förtärda alkoholens mängd och beskaffenhet $i$ olika socialgrupper}

Med fästat avseende vid trafikfylleriets förminskning och trafikskadornas bekämpande är det ännu viktigt att känna mängden och beskaffenheten av den förtärda alkoholen ävensom platsen där förtäringen i de olika socialgrupperna ägt rum.

Som ovan redan blivit omnämnt baserar sig uppgifterna om alkoholmängderna på de av de åtalade själva lämnade talen. Vad deras tillförlitlighet beträffar bör man besinna, att en med bestraffning hotad person förvisso inte önskar förhäva sig över stora mängder förtärd alkohol, utan gör snarare motsatsen. Desslikes är det mycket troligt, att beskaffenheten av den förtärda alkoholen har uppgivits vara mycket lättare än den i själva verket var. Man kan påstå, att mängden av de olika uppgivna spritdryckerna och alkoholhalterna utgörs av minimivärden, som de åtalade förtärt.

Vid klassificeringen av alkoholdrycker har den övliga indelningenn följts: starka drycker, viner och maltdrycker. Till starka drycker har med whisky, gin och cognac etc. även räknats s.k. spirituosa. Vinsorterna har inte uppdelats. Till maltdryckerna hör öl, pilsner och hemgjord svagdricka.

Tabell 6. Den förtärda alkoholens beskaffenhet $\mathrm{i}$ olika socialgrupper i \%. (Helsingfors material år 1961).

\begin{tabular}{lcrrrrr}
\hline Beskaffenhet & I & II & III & IV & V & $\begin{array}{c}\text { I \% av hela } \\
\text { antalet }\end{array}$ \\
\hline Starka drycker & 80,0 & 48,5 & 50,9 & 45,4 & 50,0 & 50,8 \\
Viner & 20,0 & 8,5 & 10,1 & 18,1 & 12,5 & 10,8 \\
Maltdrycker & - & 24,2 & 27,2 & 27,0 & 23,5 & 25,0 \\
Vägrade & - & 12,8 & 3,8 & - & 5,4 & 5,2 \\
Inget uttalande & - & 5,8 & - & 9,1 & 7,7 & 7,2 \\
\hline
\end{tabular}

De starka dryckernas andel i varje socialgrupp är ansenlig. Ungefär hälften av materialet har utmynnat i starka drycker, i den första socialgruppen till och med $80 \%$. En fjärdedel av ma- 
terialet har använt öl, pilsner och hemgjord svagdrycka. Majoriteten av ölkonsumenter förekommer i den III och IV socialgruppen / ca. $27 \%$ /. På tredje plats kommer konsumenterna av olika slags viner / $10.8 \%$ /, de förekommer rikligast i den I och IV socialgruppen; i den II gruppen utgör vinkonsumenterna endast $8.5 \%$. $5.2 \%$ vidhåller att de alls inte smakar alkoholhaltiga drycker. Procentuellt tillhör lejonparten av dessa avhållsamma den II: a socialgruppen / 12.8/. Med hänsyn till alkoholens beskaffenhet fattas utlåtande från ca. $7 \%$ av hela materialet.

För att kunna jämföra mängden av den alkohol som konsumerats i olika socialgrupper har alkoholsorterna för jämförelses skulle blivit ändrade på följande sätt: en butelj öl motsvaras av 20 cl. vin eller 5 cl. / 1 grogg / brännvin. Samtliga dessa kvantiteter innehåller 12-16 gr. abs. alkohol. 1-4 buteljer öl / beroende på sorten / motsvarande 1-2 groggar har betraktats såsom en liten kvantitet; över 8 buteljer öl / över 5 groggar / har däremot betraktats såsom en stor kvantitet. Alkoholprocenten har alltså beräknats på basis av vederbörandes utsaga. På långt när icke alla har önskat uppge den konsumerade alkoholmängden på grund av glömska eller andra orsaker.

Tabell 7. Den förtärda alkoholmängden i olika socialgrupper i $\%$. (Helsingfors material år 1961).

\begin{tabular}{lcccccc}
\hline Alkoholmängden & I & II & III & IV & V & $\begin{array}{c}\text { I \% av hela } \\
\text { antalet }\end{array}$ \\
\hline Liten mängd & 50,0 & 45,3 & 42,3 & 43,8 & 36,7 & 41,4 \\
Medelmåttig mängd & 50,0 & 42,1 & 28,2 & 31,2 & 28,1 & 31,6 \\
Stor mängd & - & 12,5 & 29,5 & 25,0 & 35,2 & 27,0 \\
\hline
\end{tabular}

I hela materialet utgör förbrukarena av små mängder lejonparten / $41.4 \%$ /. I: a gruppen uppvisade såväl små som medelstora förbrukare av alkohol ett antal av $50 \%$. Storförbrukare ingår inte alls i denna grupp. Det största antalet storförbrukare uppvisade den V / $35.2 \%$ / och den III socialgruppen / $29.5 \%$ /. I hela materialet fanns det blott $27.0 \%$ förbrukare som förtärde alkohol i stora mängder. Även detta forskningsresultat framhäver den allmänt kända skillnaden mellan de övre och de lägre klassernas dryckesvanor: de högre klassernas dryckesvanor omfattar täta rytmer, men förbrukar små engångs-drinkar, då däremot de lägre klasserna förbrukar större engångs-drinkar än de föregående, men dryckesrytmen är i jämförelse med den högre klassen med längre tidsintervaller. 


\section{Spritdryckernas förtäringsplats}

Kännedom om spritdryckernas förtäringsplats illustrerar folkets dryckesvanor och -seder även från många synpunkter. I föreliggande forskningsmaterial saknades omnämnandet av förtäringsplasen $30 \%$ i medeltal. De mest gouterade platserna var: hemmet, en bekants bostad, restaurangen, kaféet och arbetsplatsen. Bland övriga förtäringsplatser kan nämnas bilen, garaget, källaren, skrotlagret, portgången, stranden, fartyget, dansskolan.

Enligt tillgängligt material har förtäring i I: a socialgruppen till stor del ägt rum på restaurang och hos bekanta. I den II gruppen är de allmännaste förtäringsplatserna restaurang och hem. I den V och III socialgruppen kan konstateras, att egentlig dryckenskap på arbetsplats förekommit, och som rusdryck har brännvin och öl mest använts.

\section{Hos trafikfyllerister förekommande sjukdomar och andvändning av mediciner}

I tvivel underkastade trafikfyllerifall tar den till platsen tillkallade legitimerade läkaren blodprov för konstaterande av alkoholhalten och verkställer klinisk fylleriundersökning, för vilket ändamål godkänt formulär finns till förfogande. Därvid undersöks sådana motoriska och psykiska funktioner, som man av erfarenhet vet att de tydligt blir störda under inverkan av alkohol och övriga berusningsmedel. Då läkaren utfärdar sitt slutomdöme bör han även ta med i räkningen övriga faktorer som stör verksamheten, bl. a. olika slags läkemedel, förgiftnings- och trötthetsstadier, skador och sjukdomar.

Hos de i Helsingfors och Åbo undersökta trafikfylleristerna har sjukdomar av olika slag och bestående skador förekommit i överraskande riklig grad. De vanligaste sjukdomarna de lider av synas bestå av hjärt- och blodtryckssjukdomar samt magsår. Dessutom förekommer några fall av lungåkommor, sjukdomar i njurar och magspottkörtel, samt nervslag till och med fallandesjuka. Av dem som hade den längsta sjukdomslistan må nämnas : huvudinvalid, defekt vänsterhand, sockersjuka, dåligt minne.

Enligt handlingarna använder trafikfylleristerna mediciner ofanntligt allmänt och $\mathrm{i}$ rikliga mängder, i många fall till och med meningslöst. De mest använda är värk-, sömn- och lugnande mediciner. En stor grupp har använt läkemedel utan att plåga eller lida av sjukdom. Bruket av stimulerande mediciner har på sistone vunnit allt större utbredning. Det förefaller uppenbart, att för många ett rikligt bruk av blott och bart mediciner förorsakat ett tillstånd av bedövning och trötthet, som i sin tur menligt inverkat på åkningen. Dessutom bidrar många värkoch sömnmedel till att potentiera alkoholens verkan. 


\section{Sammandrag och slutsatser}

Ehuru det ovanstående trafikfyllerister berörande forskningsmaterialet är relativt ringa, inskränkande sig till endast tvenne större städer under en kort tidsperiod, torde forskningen ändock ge något slags helhetsbild av de sociala och socialmedicinska faktorerna som inverkar på trafikfylleriförseelserna hos oss. Forskningen ger klart vid handen, att trafikfylleriet är i tilltagande både i Helsingfors och Åbo betydligt mer än folkmängdens tillväxtkurva förutsätter och med utbredning till de lägre sociala grupperna. Med förbättrade arbetsmöjligheter och förtjänster och levnadsstandardens stegring för allt flere även $i$ de lägre sociala grupperna, har man råd med att äga bil eller annat motorfordon inte endast för förvärvsarbetet, utan även såsom bekvämlighets och lyxbetonat föremål.

Det är typiskt för de finska dryckesvanorna, att alkoholen bör vara stark och förtäringen skall ske fort. Även trafikfylleristerna favoriserar mera starka än lätta drycker. Som en följd härav kan konstateras, att t. ex. omkring hälften av alla i Helsingfors under 1959 uppdagade trafikfylleristers berusningstillstånd vid trafikförseelsen var till den grad uppenbar, att ett fixerande av alkoholhalten i blodet inte ansågs av behovet påkallat.

En särdeles betydande del av trafikfylleristerna i sagda städer utgörs av personer lidande av olika slags sjukdomar och defekt, som i riklig mängd använder, ofta till och med meningslöst, mediciner av olika slag. Den menliga verkan av dessa faktorer på körförmågan kan ej bedömas som liten.

Avvärjningen av trafikfylleriet är otvivelaktigt en svår uppgift. Med rigorösare straffbestämmelser kan man näppeligen förbättra läget nämnvärt. Som ett undantag kunde man kanhända tänka sig en strängare dom i de trafikförseelser, där trafikfylleristen avvikit från platsen. Enligt av Talja verkställda undersökningar utgör antalet av dem som avvikit från olycksplatsen av $54 \%$ trafikfyllerister, $23 \%$ körkortslösa och biltjuvar och resten har avvikt på grund av den mänskliga faktorn. Hos oss har den trafiklagberedande kommittén för någon tid sedan inlämnat till riksdagen ett lagförslag, som går ut på, att avvikelse från olycksplatsen och offrets lämnande på vägen skulle bestraffas med minst fängelse såsom fallet är i Sverige.

Fordringarna för återfående av körkort som trafikfylleristerna förverkat borde skärpas $i$ all synnerhet för sådana, som visat sig vara verkliga bilgangster och som även efter att ha förverkat körkortet gjort sig skyldiga till bilåkning. Många av dem som förverkat sitt körkort anser numera att de kan förfara på detta sätt, enär körkunnigheten ändock är i behåll. Detta beteendemönster ger vid handen en till den grad stark samhällsfientlig inställning, att körkort borde förvägras dessa individer på obestämd tid eller 
helt och hållet och trafiken övervakas effektivare än tillförne för annhållande av dessa individer.

Skulle man kunna motarbeta trafikfylleriet genom att omändra alkoholpolitiken? Regeringen har nyligen framställt förslag till lag syftande på lättnader i möjligheterna att erhålla alkohol. I enlighet med den nya lagen skulle man i större bosättningscentra och kyrkbyar få öppna försäljningsbutiker för alkohol, om kommunalfullmäktiga skänker förslaget sitt bifall. Man har förmenat att då alkoholen blir lättare åtkomlig för konsumenterna skulle denna omständighet förminska fyllerifallen och bidra till en övergång av tätare förtäringsrytmer och mindre engångsportioner. Liksom människornas spisnings- är även deras dryckesvanor svåra att omlägga. På grund av större lätthet att anskaffa spritdrycker vinner deras användning uppenbarligen allt större insteg och förty kan läget vad trafikfylleriet beträffar utvecklas i negativ riktning, enär även små alkoholmängder i blodet ofta kan förorsaka ödesdigra trafikolyckor.

Med den för närvarande ända till trötthet och leda bedrivna reklam- och informationsverksamheten torde i avvärjningen av trafikfylleriet inga nämnvärda resultat kunna uppnås. Såvitt upplysningsverksamheten är oberoende av nykterhetsentusiasm och baserar sig på vetenskaplig forskning av alkoholens inverkan, är det uppenbart, att förmedels informationsarbete positiva resultat kan uppnås. Enär den allmänna opinionen spelar en viktig roll som regulator för normerna i samhället, borde man få den att reagera ännu starkare än tillförne med hänsyn till trafikfylleriet. $\mathrm{Nu}$ för tiden talar man därom ganske lätt utan att betrakta saken såsom något stort brott, ehuru gärningen ofta leder till hälsans eller livets förlust för en själv, sina medpassagerare eller för personer som rör sig på landsvägen eller gatan samt dessutom till omfattande materiella förluster. Under förhandenvarande omständigheter är trafikfylleriets kardinalorsaker och påföljder av social socialmedicinsk natur. För att kunna tygla orsakerna till gärningarna inom rimliga gränser borde samhället $i$ främsta rummet dra försorg om en lämplig lagstiftning, förnuftig alkoholpolitik och effektiv upplysningsverksamhet.

Sven Erkkilä. 